\title{
MODERATION IN MANDAR PAPPASANG (A STUDY ON LAW ENFORCEMENT OF PAPPASANG IN MANDAR, WEST SULAWESI)
}

\author{
Idham \\ Balai Penelitian dan Pengembangan Agama Makassar \\ Jl. AP. Pettarani No. 72, Makassar, Indonesia \\ Email: idhambodi73@gmail.com \\ Ulfiani Rahman \\ Universitas Islam Negeri Alauddin Makassar, Indonesia \\ Jl. H. M. Yasin Limpo No. 36 Kel. Romang Polong Kabupaten Gowa. \\ E-mail:ulfiani.rahman@uin-alauddin.ac.id
}

Article received August $7^{\text {th }}, 2021$; Article revised September 20 $0^{\text {th }}, 2021$; Article approved October $22^{\text {th }}, 2021$

\begin{abstract}
Mandar as one of Indonesian ethnic groups is the majority population in West Sulawesi Province. This ethnic group has an assimilated culture with Islamic teaching values, one of which can be found in Pappasang as advices that are spoken and taught from generation to generation. This study examines Pappasang related to law enforcement. The purpose of this study is to photograph the types of Pappasang in Mandar and examine Pappasang related to law enforcement. This research is a qualitative descriptive. The data were obtained through interviews, observation, and documentation. The study showed that there were many types of Pappasang found in Mandar, such as those related to agreements, law enforcement, unity, leadership, maintaining the trust, solidarity, transparency, accountability, foresight, and so on. As for Pappasang related to law enforcement in Mandar showed many statements. One of them stated that the law is not biased towards children, family, friends or others. All are equal before the law.
\end{abstract}

Keywords: cultural moderation; mandar pappasang; law enforcement; religious moderation

\section{INTRODUCTION}

$\mathrm{M}$ oderation is a moderate attitude, neither extreme right nor left towards a phenomenon. The word moderation became very familiar, after the Ministry of Religion launched a book entitled "Moderasi Beragama" as a concept of perspective, attitude and behavior, always being impartial, acting fairly and not being extreme in religion. This means that religious moderation prioritizes balance in thinking, acting and behaving, related to living life and life itself, whether as individuals or as citizens of society living in the unitary state of the Republic of Indonesia (Kemenag 2019). For Muslims, religious moderation is synonymous with Wasathiyah Islam or a middle-line Islamic movement that has an open (incluctive), tolerant character, and spreads peace (harmony) (Turmudi 2016).

Islam is spread and developed in Indonesia in a peaceful, non-coercive way, and respects the values of local-cultural wisdom. The spread of Islam in Indonesia is through da'wah by Ulama throughout Indonesia. They teach Islam in unique ways that are packaged in art, such as wayang kulit, gamelan, and others. This way makes Islam acceptable to the Indonesian and rebuilt a new style of Islam, namely Islam Nusantara (Mubarak 2018).

The entry of Islam into Indonesia did not change the local culture, but modified it in a more Islamic and moral cultural way (Idham 2019a). Indirectly, the propagat or of Islam in Indonesia used three principles, namely adopting Indonesian culture and traditions that do not interfere with the spirit of Islam (tahmil), eliminating cultures that are not in accordance with the spirit of Islam (tahrim), and reconstructing culture and traditions (such as Sesajen, believing in symbolical supernatural) which means to one and only God (taghyir). After going through these three 
stages, then Islam in Indonesia is called Islam Nusant ara (Nashir and Si 2015).

Islam in Indonesia accommodates local culture in a highly value way. Therefore, Islamic teacching cannot be separated from culture in several Indonesian regions, it fuses in it (Idham 2019a), including in the Mandar region of West Sulawesi, as in the slogan:

Ada' makkesara', sara' makkeada';

Naiya ada', sara' nala sulo;

Naiya sara', ada' nala gassing;

Matei ada' mua' andiang sara';

Anna mate toi sara' mua' andiang ada'.

Adat is merged into the Shari'a/religion; Shari'a/religion is fused into adat;

As for custom, sharia/religion becomes a torch; As for the Shari'a/religion, custom is the strength;

A doom for custom without the Shari'a/religion;

And also the Shari'a / religion without customs (Bodi 2008).

Religious practices and behaviors that are accommodative to local culture can be used to see how far a willingness to accept religious practices that accommodate local culture and traditions. Moderate people tend to be more friendly in accepting local traditions and culture, as long as it does not interfere the main teachings of their religion. The encounter of religion with the heritage of local culture makes religion 'multi-faceted'. When religion meets local cultural variants, instantly appear various symbiotic processes that enrich each other. Plural, dynamic, and lively religious appear in the various expressions of religious life. This will ignite an accommodative and open perspective which will eventually form a moderate religious paradigm and attitude in responding reality. Radical-frontal attitudes will be far from those who make their religious beliefs accommodating to local culture.

The teachings of Islam itself uphold the values of Tasamuh, pluralism, and ukhuwah. Islam prioritizes the unity and integrity of the people, which builds civilization and humanity. As explained in several verses of Al-Qur' an: 'S. Al-Fur'an/25: 65; 'S. Al-Isra/17: 29 dan 110; 'S. Al'ashash/33: 77. These verses of the Qur'an are a form of legitimacy that Muslims are ordered to be moderate.
The local cultural approach can be the key to build a paradigm and attitude of religious moderation, and on the other hand, it can withstand the penetration of religious radicalism. An accommodative attitude towards local culture will lead to an inclusive and tolerant religious attitude, and make the atmosphere of religious life more peaceful, dynamic, and lively (Teng 2018). Religion provides color (spirit) to cult ure, while culture gives wealth to religious heritage. The encounter of religion with the t local culture makes religion "multi-faceted". When religion encounters local cultural variants, automatically various symbiotic processes enrich each other.

One of the local cultures in Mandar is Pappasang. It is an oral literature which is the legacy of Mandar ancestors passed down from one generation to the next. This contains a variety of advice that can be used as a guide in dealing with various life problems. At first, Pappasang is spoken and uttered. After the Mandar people acquainted with writing, the Pappasang were written in various writings that were spread throughout the community. However, it is still spoken orally, so that Pappasang is still known and practiced in the life of the Mandar community. Pappasang is a result of the original culture of the Mandar tribe which is still found (used) in all lines of life, especially parents in communicating with their children. Pappasang are glorified by their supporting community, then passed down from generation to generation. Pappasang consist of several forms which contain various values, including values of moderation.

Based on previous background, this research appoints one main problem, namely, how is the image of moderation in Mandar Pappasang of West Sulawesi? The problem is elaborated in two questions, namely: What is the description of the Pappasang of Mandar, West Sulawesi Province and how are the Pappasang related to law enforcement in Mandar, West Sulawesi Province?

The purpose of this study was to find out the description of Pappasang in Mandar, West Sulawesi Province and find out Pappasang related to law enforcement in Mandar, West Sulawesi Province. 


\section{Literature Review \\ Moderation Value}

Literally, one of the meanings of value in Kamus Besar Bahasa Indonesia (KBBI) is an important or useful characteristics (things) for humanity or something that completed humans according to their nature. At least it can be said that value is something that appeals to something we seek, something that pleases, something that is liked and desired, or in short, something good. Values implies positive connotation. On the other hand, something that is shunned, something that turns people away from it, such as suffering, illness or death is the opposite of it, non-value. There are also some philosophers who use the term negative value, while value in this sense called as positive value (Bertens 1993). Accortding to (Chatib 1996), Value is something that is abstract, ideal, non-concrete objects, non facts, not just a matter of right or wrong that requires empirical proof, but a matter of understanding of desires, likes and dislikes.

The word "moderat" in Arabic known as Al-Wasathiyah. In Al qur'an, this word found in Al-Baqarah/2: 143, the word wasath means the best or the perfect one. In a very popular expression stated that the best part of a problem or affair is being in the middle. Moderate is a compromise approach and is in the middle, as well as in responding differences, whether in seeing a religious issue and differences in supporting a culture. Moderates always put forward an attitude of tolerance, mutual respect, while still believing in the truth of their respective religions without neglecting the uniqueness of the supported culture. Moderation is a core teaching of a religion and culture. Being moderate is a religious understanding that is very relevant in the context of religion in all aspects. While diversity is caused by the dialectic between the text and reality itself, and the perspective on the position of reason and revelation in solving a problem.

Religious moderation mediates the middle way in religion in the midst of the rise of radical movements in the name of religion. Unfortunately, religious moderation is often misunderstood as a religious way of looking for something easy, not being serious about religion and not consistently practicing the teaching. Some other views equate religious moderation with religious liberalization. The latter view states that religious moderation is a project of liberals in campaigning for religious freedom by ignoring the principles of true religion (Rahman, et.al., 2021).

Whereas religious moderation, as described in the book "Moderasi Beragama" of the Ministry of Religion (2019), is not an inconsistent way of religion, moreover if it is seen as religious way that compromises different theological beliefs. On the other hand, religious moderation is an attitude of self-confidence and actually carrying out the principles of religious teachings, especially regarding justice and a balanced attitude. Religious moderation is also an act of being well prepared to accept and share the truth, as far as religious interpretation is concerned, as well as being receptive, open, open and able to cooperate with adherents of different religions, tribes and ethnicities.

Islam is a religion that is identical with moderation represented by the word wasatha, which means the chosen one, the best, being fair, humble, moderate, Isti'amah, teachings principle, unextreme, whether in matters relating to the world or the hereafter. Also, Islam is not extreme in spiritual or physical matters, but rather a balance between the two aspects. Ibn Jarir Atthabari referred the meaning of the word wasatha, as "the best". Meanwhile wasatha, which means fair, was put forward by many scholars, one of them, Al-Razi. Some other scholars also interpret other words such as balance and being tolerant (tasamuh) (Mubarak 2018)(Nashir and Si 2015).

Washatiyah, thus, is a fair attitude or behavior by being neutral which is in the middle, balanced and not extreme on one side (Kemenag, 2019). In the context of its relationship with different tribes, ethnicities or religions, religious moderation is a practice that can accept the existence of other religions and ethnicities, and is able to occupy the different groups fairly and proportionally.

The latest study conducted by the field of Religious Literature and Heritage of Makassar Religious Research and Development Agency in 2019, themed Religious Moderation and Oral Tradition in the community which was carried out in four 
regions, namely Maluku, South Sulawesi, East Kalimantan, and Southeast Sulawesi. The study found that the oral tradition understood by the local community was able to maintain harmony between fellow religious adherents and those of different religions, this was because the oral tradition used regional languages that were able to touch the hearts of the speakers and listeners (Muslim, et.al., 2019).

Idham's article (2019) entitle "Moderasi dalam Budaya Masyarakat Islam" highlights the problem of Islamic moderation in Indonesia which in the last 20 years has been questioned by many people and even internationally. The question is wondering on Islam in Indonesia, which is friendly for hundreds of years, but suddenly becomes stern. This can be seen from the intolerance present by terrorist groups as well as Muslims towards other religious groups, even Muslims who disagree with them. Moderation of Islam is the concern of the article, where it is found that the moderate attitude of Muslims in Indonesia at the beginning of independence formed a peaceful Indonesia, even though plural in embracing a religion. The loss of moderation can lead to clashes among the citizens.

Based on the above understanding, washatiayah or moderation in Islam, actually contains three principles, namely: Justice (aladl), Balance (tawazun), and Tolerance (tasamuh) (Muchlis Hanafi et al, 2012). These three things will be explained in the Mandar Pappasang on the research findings.

\section{Pappasang}

Pappasang can be translated as a message (Idham, 2008). Even the real meaning is advice or wise speech. Pappasang also means wills or ancestral advices as a source of information for present and future generations. Pappasang emphasizes more on moral teachings that should be followed and highly respected, not only seen as expressions. It is able to knock on hearts and minds so that people are honest and think by using common sense (Sikki, 1998; Ekawati, 2019).

Pappaseng for Mandarese is the same as Pappaseng for Buginese and even Makassarese. Pappaseng is an expression of language or speech with great potential for the smooth transformation of noble values and vital ideas from one generation to the next (Alam 2000). This statement reinforces the assumption that Pappaseng is a medium that functions as a tool to convey and instill cultural values from one generation to the next. Therefore, the system of values that once existed in the community remains actual and becomes the basis of the community life that supports it (Abbas 2013).

The Mandar society knows Pappaseng in various forms and types, depending on the media used to convey it. Among others, in the form of stories (tolo'), songs (elong), and poetry (kalinda'da'), as well as in the form of messages (Pappaseng), and etc. As for the focus of this paper, Pappaseng is spesified in the form of short prose narratives, which are usually only expressed by older people who related to cultural and religious moderation in society.

\section{Law Enforcement}

Law enforcement is the process of making efforts to enforce or to function legal norms as guidelines for behaving in legal relations in social and state life (Rofifah 2020). From the subject point of view, law enforcement can be carried out by a broad subject and can also be interpreted as an effort to enforce the law involving all subjects. It is also an effort to perform ideas on justice, legal certainty and social benefits into reality (Mahmud and Marzuki. 2012).

The essence of law enforcement is justice. Justice itself has various meanings, depending on the perspective (Rosidin, Setiawan, and Rusliana 2019) (Rumadan 2017). In any country, various problems often arise regarding the enforcement of justice in the realm of law. The concept of justice that has been established in a country is not necessarily good if it is applied to other countries. However, it is possible that there is mutual influence or integration between one's thoughts on the meaning of justice, especially those with universal nature. At the philosophical level, of course, each country has its own roots of thought, depending on the basic norms of the country and the sociocultural life of its nation (Susilo 2018).

Law enforcement is a way of turning ideas and concepts into reality. According to 
Soekanto (1983), conceptually, the essence meaning of law enforcement lies in harmonizing the relationship of values described in solid rules and attitude decisions to create, keep and maintain peaceful social life.

Legal values that live in a society that can be used as legal content are usually in the form of local wisdom of the local community (Saptomo 2010).

Internalizing the values of local wisdom into law will increase the role of the legal culture of a society. Thus society can achieve the purpose of the law, namely, justice, expediency, and legal certainty. A step that is no longer difficult to go through is the realization of the state's goals, as stated in the preamble of the 1945 Constitution (Nasution 2014).

\section{DISCUSSION}

Mandar is one of the tribes with the majority population of West Sulawesi Province. Aside form known as ethnicity, Mandar also means territorial and value. Territorially, the Mandar region is now the Province of West Sulawesi. Before this Province was formed, in the kingdom era, it consisted of fourteen kingdoms. In the Dutch era, it was included in the Mandar afdeling which consisted of four onder afdeling, namely Majene, Polewali, Mamasa, and Mamuju. The Mandar as a value can be found in the expression sipamandar, mutually reinforcing, and so on. As an ethnic group, Mandar has a culture that has been passed down from generation to generation called Pappasang.

\section{Types of Pappasang in Mandar}

Pappasang in Mandar is included in all lines of community life. Pappasang is one of the peaks of cultural values in a sense of kemandar-an. It is necessary to add various policy concepts from the noble values of independence related to society, including:

\section{a. Agreement}

Mua' purami dipallandang bassi' pemali diliai, mиa'purami, di pobamba pemali dipepondo'i disesena attongangan. Bassi' tambbottu petabung tarrabba.

(If it has been determined that something is forbidden to step over, if it has been said/agreed upon, it cannot be denied, the rules must be continued according to the principle).

\section{b. Law enforcement}

Naiyya ada' tammalo pai dipasoso 'tatti tonggang pai lembarna, takkeindo pai, takkeamapai, takke lelluluare' pai, takke sola pai, takkewali pai andiappa to dikalepa'na andiang to di suliwanna, andiang to na poriona, andiang to nabire'na Tammappucung tandoppas toi

(The so-called law enforcement agencies are firm in making decisions, not being impartial, motherless, fatherless, relativesless, having no friendless, having no enemies, not being tempted by pleasure, having no subordinates and never being greedy).

Mua tau sala timbei mau na sakkaniing banning sallisar, тиа' toparua amasei mau nasappamera'na sallambar.

(if guilty is proven, punish them, even if it is only a roll of cotton, punish them, and if they are on the right side, even if it is only a piece of sin, correct it).

c. Seeking for truth (Puang Sodo)

Appei ruppanna uru bicara tutumasagala balibali palalo balibali. Sa'be balibali

(There are 4 points to decide on a problem: researching and analyzing both parties' statements, valid words from the families of both parties, trusted witnesses, and both parties)

\section{d. Democration (Mallikrodt)}

Mua' mendi-mendi oloi elo'na to arajang disesena odiada' odibiasa, turu'i ada' mua' mendi-mendi oloi elona ada' disesena odiada'odibiasa, turu'i toarajang

(If the wishes of the king's nobles are a bit ahead in accordance with traditional customs and habits, then the traditional nobles should join and vice versa).

\section{e. Autonomy (Daetta Kanna I pattang)}

Madondong duangbongi anna diang api dinaung bakarna napideitoi tia alabena, mua'andianni mala napideitoi pendoamo'o lao diindo ada'mu, mua pitumbongi pitunggallo andiangi mala mupi'dei siola indo ada'mu, pendoa moo diama ada'mu apa nasiolamo'o mappi'dei.

(The next day, if there is a fire burning in an area, it is best if the fire can be extinguished by yourself and if it cannot be handled, you should ask your traditional mother for help. If seven days and seven nights cannot be quelled, you should come to your traditional father to quell the fire together). 
Kaiyyang tammaccinna dikende'-kende'na, kende'-kende' tammaccina dikaiyanganna

(those who govern should not impose their will on people, and the people should not impose their will on those who govern).

\section{f. Leadership Concept (Tomatindo Dilangganna)}

Pallaku lakuanni mie lita'mu, apa' madondong duambongi inai-inai mala mappatumballe' lita' di Balanipa, ia tomo 'tia na dianna dai dipeuluang, na dipesokkoi anna malai toma'tia naung di tambing mengngada' dai

(Defend your homeland. If tomorrow the day after tomorrow, whoever can save the country of Balanipa has the right to be appointed as the leader, and I will abdicate and support with all my heart.).

Mara'diamo tu'u na maasayangngi banua siola pa'banua, anna mara'dia tomo rapang ponna ayu na naengei mettullung pa'banua.

(It is the king who will love the country and the people, and the king is like a tree where the people take refuge)

\section{g. Unity (Ammana Wewang / Ammana Pattolawali)}

Dotai tau siamateang mie na membere di olona lita' dadinanaparenta tedong pute to kaper.

(it's better to die under the ground than to be ruled by the infidel Dutch)

Unity between Pitu Babana Binanga and Pitu Ulunna Salu (Allamungan Batu / Sipamanda' di Luyo)

- Ta'lemi manurunna paneneang uppasambulobulo ana appona di Pitu Ulunna Salu; Pitu Ba'bana Binanga. nasa'bi dewata diaya Dewata doing, Dewata di kanang Dewata di Kairi, Dewata diolo Dewata di boe', menjarami passemandarang.

- Tannipasa' tanniatonang, ma' allonang mesa malatte samballa, siluang sambu-sambu sirondong langi'langi', tassipande peo'dong tassipande pelango, tassipelei di panra tassialuppei diapiangang.

- Sipatuppu diada' sipalele dirapang, ada' tuho di Pitu Ulunna Salu, ada' mate di Muane ada'na Pitu Babana Binanga.

- Saputangan di Pitu Ulunna Salu, simbolong di Pitu Babana Binanga.

- Pitu Ulunna Salu memata di sawa. Pitu Babana Binanga memata di mangiwang.

- Sisara'pai mata malotong anna mata mapute, anna sisara' Pitu Ulunna Salu Pitu Babana Binanga.

- Moa' diang tomangipi mangidang mambattangang tommu-tommuane, namappasisara' Pitu Ulunna Salu Pitu Babana Binanga, sirumungngi anna musessei, pasungi ana'na anna muanusangi sau di uai tammembali'.

- It has been proven that the supernatural powers of the ancestors unite their children and grandchildren at Pitu Ulunna Salu and Pitu Babana Binanga, above the supernatural powers of the Dewata (God) which are stronger than the Gods below. The gods on the right, the gods on the kin, the gods in front of the other gods, then be born the union of whole Mandar.

- Unchecked, borderless, united with a single mat, covering the body with the ceiling, not giving each other food that makes each other boneless, not giving each other intoxicating and poisonous drinks, not leaving each other in trouble, not forgetting each other's goodness.

- $\quad$ Respect each other law and rules, the law lifes in Pitu Ulunna Salu, death punishment on its customary husband Pitu Babana Binanga.

- $\quad$ Pitu Ulunna Salu keeping the snakes (enemy from the land), Pitu Babana Binanga eepinf the sharks (enemy form the sea).

- When the black part of eye is separated from the white, only then Pitu Ulunna Salu with Pitu Babana Binanga can be separated.

- Whoever dreams of dreaming of a boy who will separate Pitu Ulunna Salu with Pitu Babana Binanga, agreed to dissect the pregnant belly immediately, then remove the baby boy, then drift into the water that is impossible to return)

\section{h. Maintaining trust}

Ropo'mo'o mai bulang, tilili'mo'o sau buttu, tannaulele diuru pura loau, dotami iyami' sisara' uli'i anna iya sisara' uru pura loai.

(If the moon will fall, then fall, the mountains will fly away, but I will not move from my first word, it is better for our heads to be separated from the body than to deny our own oath).

\section{i. Solidarity}

Naruao lembong narua toa', tumbiringo'o na mallewaima', tallango'o na mattimbaima, nyawa siandarang, cera' silolongngi.

(if you were hit by the waves I would also hit, if you were shaken I would stabilize, you drowned I drifted, soul drifted together, blood flowed together) 
j. Transparancy (the advice of Todilaling before died)

Madondong duambongi anna matea' mau ana'u mau appou, da muannai dai' di pe'uluang mua' mato'dori paunna, masu'angi pulu-pulunna, apa iуamo tu'u na marruppu-ruppu' banua.

(If tomorrow I past away, eventhough children and my grandchildren, do not promote them as leader if they are being rude, and bad behave, because this type of person would destroy the world)

\section{k. Further insight}

Sailei gau' pura lao, pe'gurui tongangi gau' mamanya, na mupijarammingi disese apianna gau' manini' makkeguna di alawemu anna lita'.

(look at the deeds that have been done in the past, learn seriously the actions of the present, so that they become a mirror and they are useful for you and for the homeland).

\section{Accountability}

Accountability in Mandar culture has advantages over other accountability because it is not the accountability of a particular agency or community. In Mandar, the individual accountability refers to nature (God), humans, and to oneself.

Alawe membolong di nawang, nawang membolong di alawe, alawe membolong di akkeadang, akkeadang membolong di alawe, alawe membolong di atauang, atauang membolong di alawe.

(The self of human is part of nature (God) and nature is part of the human, the human is part of social customs and social customs are part of the human, the human is part of his own personality and the human is part of himself).

\section{m. Supervision}

Naiya mara'dia, tammatindoi di bongi, tarrarei di allo, na mandandang mata di mamatanna daung ayu, di malimbonganga rura, di madinginna lita, di ajarianna banne tau, di atepuanna agama.

(It is the duty of a Mara'dia, it is not permissible to sleep well at night, to remain silent and to sit idly during the day. A mara'dia must think about the fertility of the soil, the breeding of plants, the abundance of ponds and fisheries, the peace and security of the country, the health and development of the population and the perfection of religious teachings)

If on the contrary, then loppa'lita' would appear (land becomes hot), sai (falling plant), polei pangolle' (flood), mangandei api (fire), mara'eitana -tanang (dry plant), this sistuation would torture the people. n. Profesionalism

Diajumai pai tu'u mesa gau' anna dialai asselna, assalnamo tu'u mappannassa di marorona pau, kedo. anna gau' anna malla makkeguna di alawe, di jama jamang anna lita'.

(Through hardworking then a person can contolr himself which reflected from the way he speaks, behave, and socialize in order to make him useful for the country)

Nakodai mara'dia anna banua kaiyang toilopi.

(Mara'dia only as captain and binua kaiyang is the conqueror of boat/archipelago)

In addition to the values mentioned above, there are many more ke-mandar-an values that need to be inventoried for revitalization and actualization in the daily life of the Mandar people, for example noble policies, high work ethic, positive thinking, respecting science and technology, acting responsibly, professional, healthy competition and toughness (Bodi 2008). When the values are reliable for the life wherever and whenever, it is already ensure that Mandar people would be tough in facing all troubles that possible to change their value orientation in order to deal with upcoming impact from this globalization era.

\section{Moderation in Law Enforcement, Pappasang in Mandar}

Moderation which in the language of religion (Islam) is known as Washatiayah, actually contains three principles, namely: Justice (al-adl), balance (tawazun), and tolerance (tasamuh) (Tim, 2019; Idham, $2019 b)$. This concept is elaboreted more in Mandar Pappasang, specifically in observing law enforcement.

A peaceful and loving life is not only the right of every citizen, but also part of the necessities of life for every human being. It is hard to imagine life without security. Human activities, both socially and individually will always be haunted by threats (Syaeba 2013). Therefore, the law exists to regulate human behavior so that their actions do not endanger the lives of others. Protection of humans, in law referred to as criminal law which is intended to provide a sense of secure feeling to each individual or group. This feeling can be a feeling of calm, peace and freedom from all things that can harm themselves and the group. In this case, the loss in question is not only related to material losses, but also immaterial. 
In addition to ensuring the implementation of a peaceful life, the law also aims to fulfill a sense of justice for every human being in order to create a balance of life in the relations of social life, and this has long been a concern of the Mandar community (Ilyas 2019). This is seen in pasang which related to law matter. At least there are some points of meaning in pasang on this law enforcement, one of them is about law independence, justice, treatment of people who violate the law, also the imporatnce in understanding and explaning the law (Ridwan, Thal;ib, and Baharuddin 2020). Based on researcher observation, the core of each pasang is related, and even completed each other.

Justice, which is the main foundation in every law enforcement, can only succeded if the law adheres to the principle of maroro tanddibassi (independent), while maroro tanddibassi itself become the basis of justice and applicable legal provisions (Argariawan 2018). This principle was embraced by the ancestors of the Mandar community in the past. For them, a just law is part of the supremacy of the moral foundation of social life, and it is not only carried out in the customary environment, but also in the sphere of domestic life (Idham 1997). As for the details, below is the example of pasang:

“Naiyya ada' tammaelo pai dipasoso', tatti tonganggpai lembarna, ta keindo pai, takkeama' pai, ta'ke leluare' pai, take sola pai, ta'kewali pai, andiappa to dikelepa'na andiang to di suliwanna, andiang to na poriona, andiang nabire'na tammappucung tandoppas toi"

(The so-called law enforcers are firm in making decisions, not impartial, a motherless, fatherless, having no relatives, having no friends, having no enemies, not being tempted by pleasure, and having no subordinates and being greedy).

In pasang mentioned several principles that must be possessed by law enforcers, namely, being firm in making decisions, being fair or impartial, and being indiscriminate, even though those who violate the rules are enemies, friends, relatives and even their parents. In addition, this pasang also emphasizes the importance of law enforcers being professional, that the personal affairs of law enforcers should not be mixed with legal matters, because this has the potential to make law enforcers not act fairly.
Meanwhile, the other three characters stated that the law enforcer should not be dazzled by worldly pleasures, have no subordinates and be greedy, because things like this will also make the law progress unproperly.

Law in Mandar is likened to lembar (stick). Lembar usually used by famrmer to bear the harvest. Besides functioning to make it easier for farmers to carry their luggage, Lembar also acts as a counterweight.

The position of law enforcement in Mandar is like lembar which serves as a mediator or balancer. Lembar used as a symbol of law enforcement in order to facilitate the meaning of the nature of the law which must always in balance, based on the principles of truth and justice. This symbol of meaning also makes it clear on the one hand that reality has always been the basis of knowledge of the Mandarese in the past, and of course it was not born instantly, but through a long process of contemplation and then concluded that if you want to see the actual form or model of justice, then try to see and learn from lembar.

"Mua to sala timbei mau sakkani'ing bannis sallisar, mua to parua amasei mau na sappamera'na sallambar"

(If someone is guilty, throw it even if it is only a small throw, if someone is right, protect it even if it is just a betel leaf).

Pasang related to matters as law enforcement, it is stated that when someone is guilty no matter how small it is, then the person should be punished (read;thrown), also, if someone is right, then protect him even if it is only a betel leaf. The point, no one is above the law, paiyai o iya, pataniai o Tania (correct the right, and guilt the wrong).

The manifestation of the implementation of law enforcement is not just words, but has actually happened in the history of the Mandar people in the past, right during the leadership period of puang caddi. At that time, Puang Caddi punished his own son for violating customary rules, for killing his playmate when Papuangan had to punish their own children for violating the applicable rules. So, he himself had to slaughter his son. This is a form of legal independence that is far from matters of family relations, kinship and friendship, firmness is something that is 
absolutely done in an effort to enforce the law in Mandar land at that period.

“Appe’i rupanna mapputus masaalah: uru bicara, tutumasagala bali-bali, palalo bali-bali, sa'bi balibali”.

(There are four main things in deciding a problem, namely; examine the root of the problem, analyze the words of both parties, the valid words of both parties, the trusted witnesses of both parties).

Pasang is a technique or method of seeking the truth in order to determine justice. According to Darmawan Mas'ud Rahman, this Pasang was applied by the Mara'dia (leaders) in Balanipa when resolving the ongoing dispute. The essence of this Pasang explains the importance of knowing the root of the problem before deciding a case, and this applies not only to law enforcers but also to leaders.

Knowing the root of the problem is very important in every case because it is impossible for every problem that occurs without a cause. So it also needs to be investigated so that the subject matter is straightforward. After that, further analysis was carried out by listening to the words of the two warring parties. This is a follow-up to the analysis of the core problem in strengthening the results that have been carried out previously, and also to strengthen all these analyzes. Therefore, it is necessary to hear the arguments of the family and trusted witnesses from both parties, so that the issues in dispute find a bright spot, and sit down. real problem. Therefore, through this pasang, we can understand that the legal issues in the land of Mandar are issues that are full of prudence, requiring analysis, opinions, and arguments from various parties. Likewise, in the case of legal decisions, reliable witnesses are also needed, so that the legal decisions are truly fair.

Attoganan parallui di da'dua tau: mesa tau iya mappahangi anna mesa tau iya mappannassai.

(Truth matters to two people, someone who understands, and someone who explains it).

In order to decide the truth of a decision, required two important things; a person/people who understands the law, and who can explain the legal issues. These two things are essential to be noticed because the truth must depart from a deep understanding and an effort to explain the meaning of the essence of a truth, which is the basis of legal decisions. The goal is the decision does not harm the two parties, whether the loss is material or immaterial. In law, understanding and explaining the truth is an inseparable unity. Law can only be explained well when it is well understood.

Moreover, man and truth are an inseparable unity. If we want unity to continue as it should be, then truth must remain the principle of life for humans. It is based on the pasang that reads"Rupa tau anna Attonganan da mupasisara'i anna da tau tuo sisara-sara"'. It means; Truth and humans should not be separated so that we do not fall apart.

Mua' diang pambareang papiai barena, da mucekoi parammu rupa tau.

(if there is a distribution, divide it fairly, do not cheat on your fellow human beings).

Pasang convey the importance of being fair in terms of distribution. The word papiai barena in pasang is an affirmation of the importance of sharing fairly because there are so many problems that occur only because of the issue in sharing. Also, a country is threatened with disbandment because of this injustice issue.

Pasang might sounds flat, but it is full of social meaning, which is not only related to human relations, but also the future of a nation. Ibn Khaldum in his book Mu'adimah explains that:

Based on social theory, it is stated that the strength of a nation or the birth of trust among others, one of which is based on this fair attitude, division and prolonged conflict will be very easy if justice is not enforced, similarly, peace will be difficult to achieve when injustice becomes dominant in life behavior, KH. Abdurrahman Wahid famous statements "Peace without justice is an illusion".

'E ana' dao melo' diarakke' timbulu-bulu, apa duanrupai tu'u diarakke'; daiarakke'i kanene diarakke tongan, naiyya tia dinawa-nawai dipatei, anna diarakke'i saiyang diarakke' tongan, naiya tia dinia'i disapu, digangga'i dipissawei anna di ba'ba' $i$ '

(O my son, do not expect to be feared, for there are two animals to be feared, the crocodile and the horse. However, crocodiles are always targeted to be killed, while horses are used to be petted, restrained, ridden and then beaten). 
In the past, Pasang is satire of traditional leaders against a Mara'dia in Mandar, namely when the traditional elders who were members of the ada' appe banua kaiyang commemorate Mara'dia Tonijallo as the third Mara'dia in the government structure of the Balanipa kingdom. According to Darwaman Mas'ud Rahman Mara'dia Tonijallo is a son of Todilaling beribu people of Balanipa and served as Mara'dia matoa (wakil Mara'dia) during Tommepayung's leadership as Mara'dia Balanipa.

At first the leadership of Mara'dia Tonijallo accepted by local customs and the people, but because of his unnatural power ambitions and arbitrary treatment and no longer heeding warnings ada' which applicable in Balanipa, make himself no longer considered as indo ama (protector) of the people, so that Ada' Appe Banua Kaiyang commemorate it by issuing the statement because the people still ignored the warning, until Mara'dia Tonijallo died without knowing the cause.

The same thing happened to the fifth Mara'dia with the title Todigayang. Someone killed him because his role as a leader was not by the customs that prevailed in Mandar Balanipa. This review also illustrates that law enforcement in Mandar land in the past was a pretty severe problem and often even ended in death. The moral message conveyed in this pair applies to law enforcers and leaders or Mara'dia at that time.

Warning through this satire sentence shows a polite way of criticism, but full of deep meaning. The parable of Pasang above shows that a king or leader should not be overdose by authority as happened to Mara'dia Tonijallo and expect his people to be afraid of him because the power of the people has a very negative effect on the government system and often even makes the leader fall from his seat of power.

Another thing that illustrates this pair is the steadfastness of traditional institutions members of Appe Banua Kaiy who carry out their mandate as traditional institutions. They are aware that an authoritarian and arbitrary leader towards the people is quite dangerous because the fear he creates can give birth to disapproval, dislike, and hatred, which will eventually lead to resistance and conflict, just like people afraid of crocodiles. Fear is not to run forever but to find a way to kill him.
Likewise, with horses, even though they are feared, there are efforts to tame them so that they can be used later.

In short, pasang conveys human arbitrariness, especially in terms of power, does not last forever. There are only two possibilities, he is hostile or being used subtly, like a horse being petted, restrained, ridden, and then beaten. Therefore, the tide indirectly asks every leader or policymaker to maintain a moderate (moderate) attitude under the legal principles and rules in a society.

“Andiangi mala mapocci' mua' anu malakka, anna andiang toi mala malakka mua anu mapocci,"

Something that has been determined in length cannot be short, and something that has been determined short can not be long.

The essence of this pasang conveys that something that has been determined in its rate cannot be changed, that something must run according to its principles. In Mandar, people who change provisions on personal initiative and not on the deliberation results are termed marrusoi allewuang (people who spoil the outcome of the agreement).

Likewise, things whose provisions are theological, apart from being immutable, will also be considered against God's provisions, because in general, the Mandar people believe that the faces are God's provisions that cannot be changed. In contrast, human behavior and actions can be changed. Changed, as the sound of the pasang "rupa ditia tammala dipinra, kedo malai tia dipinra" means; only faces cannot be changed, but human nature and actions can change.

The point is, Pasang emphasizes the importance of being consistent in viewing and determining a provision. It is not justified to impose a will in viewing and changing existing provisions unless the provision is related to social affairs, and that must be discussed first.

\section{CLOSING}

Religion does not come in an offensive mode and bring the presence of eliminating the local variants it approaches. On the other hand, religion exists to enter and diffuse to influence a community's cultural image without losing its religious identity or locality. So that religion and local culture are intertwined and complement each other, which is manifested in the attitude of cultured 
religious wisdom and culture based on religion, as has happened in many regions in Indonesia, including Mandar. It is very much found in various Pappaseng. Pappaseng in Mandar, as stated above, contains the value of Islamic teachings, especially in Pappaseng related to law enforcement in Mandar.

Pappaseng Mandar, as a local wisdom, continues to grow and is passed down from generation to generation. For the most part, this local wisdom is an unwritten law but is maintained and continues to grow in the community called Pappaseng. Pappaseng related to law enforcement is an inheritance in the values of life integrated into the form of religious law for the Mandar people. This local wisdom is part of the legal system that develops in the national legal system. Pappaseng, especially law enforcement, is a living law that develops in the life of the community. Pappaseng is an unwritten legal order, but it can be used as a guide for the supportive community so that the community order runs well. This Pappaseng can be used as a guideline or source of law to determine written regulations if set out in a statutory regulation as the applicable law in the national legal system.

\section{ACKNOWLEDGEMENT}

Author realizes that this research will not be completed as expected without the help and participation of various parties. Therefore, the author would like to express his deepest gratitude and appreciation to all those who have helped conduct this research.

\section{REFERENCES}

Abbas, Ibrahim. 2013. "Criteria of Ideal Leadership by Lontaraq a Study for Learning Materials of Social." Int. J. Hist. Educ. 26 (2): 169-170.

Alam, Saleh. 2000. Nilai Budaya Yang Terkandung Dalam Pappasang: Suatu Ungkapan Luhur Orang Makassar Di Kabupaten Gowa. Makassar: Laporan Penelitian Depdikbud Sulawesi Selatan. Makassar: Laporan Penelitian Depdikbud Sulawesi Selatan.

Argariawan, Tamsil. 2018. "Representasi Nilai-Nilai Pappasang Di Tanah Mandar (Studi Hermeneutika Fenomenologi)." E-Prints: 1-10.
Bertens, K. 1993. Etika. Jakarta: PT. Gramedia Pustaka Utama.

Bodi, Muh. Idham Khalid. 2008. Local Wisdom: Benang Untaian Mutiara Hikmah Dari Mandar Sulawesi Barat. Jakarta: Nuqtah.

Chatib, Thoha. 1996. Kapita Selekta Pendidikan Islam. yogyakarta: Pustaka Pelajar.

Ekawati, Dian. 2019. "Embedded Local Wisdom to Education : The Pappaseng Local Wisdom to Improve Students , Leadership Attitude." https://doi.org/10.4108/eai.27-42019.2286832.

Idham. 1997. "Sibaliparri Pada Masyarakat Pantai Desa Kenje KecamatanCampalagia Kabupaten Polmas." PPs UNM Makassar.

Idham. 2019a. Moderasi Dalam Budaya Masyarakat Islam. Jakarta: Badan Litbang dan Diklat Kementerian Agama RI.

Ilyas, Husnul Fahimah. 2019. "Nilai-Nilai Luhur Dalam Pappasang Masyarakat Mandar." Pusaka Jurnal Khazanah Keagamaan2 7 (2): 203-18.

Kemenag, Tim. 2019. Moderasi Beragama. Jakarta: Badan Litbang dan Diklat Departemen Agama RI.

Mahmud, Peter, and Marzuki. 2012. Pengantar Ilmu Hukum. Jakarta: Kencana Prenada.

Mubarak, Ahmad Agis dan Diaz Gandara Rustam. 2018. "Islam Nusantara: Moderasi Islam Di Indonesia.” Journal of Islamic Studies and Humanities 3 (2): 153-68.

Nashir, Oleh H Haedar, and M Si. 2015. "Moderasi Indonesia dan Keindonesiaan Perspektif Sosiologi," $1-84$.

Nasution, M. 2014. Budaya Hukum Indonesia. Jakarta: Analisa.

Muslim, A., Idham, I., \& Subair, M. (2019). Iko Iko Siala Tangang (Tracing Moderatism of Religious Concept From the Oral Traditions of Bajau). In International Conference on Religion and Education.

Rahman, U., Mujizatullah, M., Subair, M., Idham, I., Muslim, A., Kila, S., ... \& Nensia, N. (2021). Religious and Cultural Moderation of Ambonese 
Society Post-1999 Conflict. Linguistica Antverpiensia, (2), 2225-2243

Ridwan, Hambali Thal;ib, and Hamza Baharuddin. 2020. "Implementasi Nilai-Nilai Hukum Adat dalam Mewujudkan Hukum Yang Bersendikan Kearifan Lokal.” Journal of Lex Theory 1 (2): 116-28.

Rofifah, Dianah. 2020. "Eksistensi Kearifan Lokal Dalam Sistim Peradilan Di Indonesia.” Paper Knowledge . Toward a Media History of Documents, no. 1: 12-26.

Rosidin, U, A I Setiawan, and I Rusliana. 2019. "Kearifan Lokal Sebagai Sumber Hukum Dalam Pengembangan Perundang-Undangan Nasional (Local Wisdom As a Legal Resource in the Development of National Legislation)." Conference Proceeding ICONIMAD, International Conference on Islam in Malay World IX, Krabi, Thailand. http://cis.psu.ac.th/iconimad2019/proc eedings/21_p390-401 Kearifan Lokal Sebagai Sumber Hukum dalam Pengembangan Perundang-Undangan Nasional - Utang Rosidin-INmelayu.pdf.

Rumadan, Ismail. 2017. "Peran Lembaga Peradilan Sebagai Institusi Penegak Hukum Dalam Menegakkan Keadilan Bagi Terwujudnya Perdamaian.” Jurnal Rechts Vinding: Media Pembinaan Hukum Nasional 6 (1): 1-20. https://doi.org/10.33331/rechtsvinding. v6i1.128.
Saptomo, Ade. 2010. Hukum dan Kearifan Lokal. Jakarta: Grasindo Press.

Sikki, Dkk. 1998. Nilai dan Manfaat Pappaseng Dalam Sastra Bugis. Jakarta: Pusat Pembinaan dan Pengembangan Bahasa Departemen Pendidikan dan Kebudayaan.

Soekanto, Soejono. 1983. Faktor-Faktor Yang Mempengaruhi Penegakan Hukum. Jakarta : Rajawali. Jakarta: Rajawali.

Susilo, Agus Budi. 2018. "Penegakan Hukum yang Berkeadilan dalam Perspektif Filsafat Hermeneutika Hukum (Suatu Solusi Terhadap Problematika Penegakan Hukum Di Indonesia)." Jurnal Hukum Dan Peradilan 2 (3): 449. https://doi.org/10.25216/jhp.2.3.2013.4 49-470.

Syaeba, Muhammad. 2013. "Budaya Mandar Pappasang Hubungannya Dengan Pembinaan Moral Masyarakat.” Jurnal Pepatuzdu 5 (1): 1-14.

Teng. 2018. "Open Access Social Messages of 'Kajaolaliddong' in Living Harmony : A Historical Perspective." Am. J. Humanit. Soc. Sci. Res. 07 (2): 39-44.

Tim, Kementerian Agama RI. 2019. Moderasi Beragama. Jakarta: Badan Litbang dan Diklat Departemen Agama RI.

Turmudi, Endang. 2016. "Islamic Twists and The Decline of Islamism In Indonesia." Jurnal Multikultural \& Multireligius 15: $1-12$. 